\title{
Sensory acceptance and characterization of yoghurt supplemented with yacon syrup and cashew apple extract as a source of bioactive compounds
}

\author{
Aceitação sensorial e caracterização de iogurte suplementado \\ com xarope de yacon e extrato de caju como fontes de \\ compostos bioativos
}

\section{Ana Hérica de Lima Mendes ${ }^{1}$, Ana Paula Dionísio ${ }^{2 *}$ (D), Carlos Farley Herbster Mouta², Fernando Antonio Pinto de Abreu², Claudia Oliveira Pinto², Deborah dos Santos Garruti², Idila Maria Araújo²}

${ }^{1}$ Instituto Federal do Ceará (IFCE), Limoeiro do Norte/CE - Brasil

${ }^{2}$ Embrapa Agroindústria Tropical, Fortaleza/CE - Brasil

*Corresponding Author: Ana Paula Dionísio, Embrapa Agroindústria Tropical, Rua Dra. Sara Mesquita, 2270, CEP: 60511-110, Fortaleza/CE - Brasil, e-mail: ana.dionisio@embrapa.br

Cite as: Mendes, A. H. L., Dionísio, A. P., Mouta, C. F. H., Abreu, F. A. P., Pinto, C. O., Garruti, D. S., \& Araújo, I. M. (2019). Sensory acceptance and characterization of yoghurt supplemented with yacon syrup and cashew apple extract as a source of bioactive compounds. Brazilian Journal of Food Technology, 22, e2018153. https://doi.org/10.1590/1981-6723.15318

\begin{abstract}
Yacon syrup (YS) and cashew apple extract (CAE) are products with high concentrations of bioactive compounds such as fructooligosaccharides and carotenoids, which exhibit prebiotic and antioxidant properties. The objective of this work was to evaluate the impact of YS and CAE on the chemical, physical, physicochemical and sensory properties when these products were incorporated into natural yoghurt. Initially, the YS and CAE were characterized by chemical, physical and physicochemical analyses. The bioactive compounds, such as carotenoids, fructooligosaccharides and phenolic compounds, and the antioxidant activity were also determined. After characterization, natural yoghurt was supplemented with YS and CAE in different concentrations as follows: formulation A (non-supplemented yoghurt, as the control), formulation B (yoghurt with the addition of $20 \%$ of YS), formulation C (yoghurt with the addition of $20 \%$ of YS and $10 \%$ of CAE) and formulation D (yoghurt with the addition of $20 \%$ of YS and $20 \%$ of CAE). The formulations were evaluated for their sensory acceptance (overall acceptance, texture and appearance) and purchase intent, and were then characterized by chemical, physicochemical and physical analyses. The results indicated that the YS and CAE presented high concentrations of bioactive compounds, such as fructooligosaccharides and carotenoids, respectively. In addition, when the yoghurt was supplemented with these products, this induced changes in the chemical, physicochemical and physical properties of the yoghurt. In the sensory analysis, all the formulations presented good acceptance. The results indicated that yoghurt could be considered as an interesting vehicle for YS and CAE, products with high levels of bioactive compounds that may exert beneficial effects on human health.
\end{abstract}

Keywords: Prebiotic; Dairy products; Smallanthus sonchifolius; Anacardium occidentale. 


\section{Resumo}

O xarope de yacon (XY) e o extrato concentrado de caju (ECC) são produtos que apresentam elevadas concentrações de compostos bioativos, como fruto-oligossacarídeos e carotenoides, que exibem propriedades prebióticas e antioxidantes. O objetivo deste trabalho foi avaliar o impacto de XY e ECC nas características químicas, físicas, físico-químicas e sensoriais, quando estes produtos foram incorporados em um iogurte. Inicialmente, o XY e o ECC foram caracterizados através de análises químicas, físico-químicas, físicas e de compostos bioativos (carotenoides, fruto-oligossacarídeos, compostos fenólicos e atividade antioxidante). Após a caracterização, o XY e o ECC foram adicionados ao iogurte natural em diferentes concentrações, sendo estas: formulação A (sem adição de XY e ECC), formulação B (iogurte com adição de $20 \%$ de XY), formulação C (iogurte com adição de $20 \%$ de $X Y$ e $10 \%$ de ECC) e formulação D (10\% de ECC e iogurte com adição de $20 \%$ de XY e $20 \%$ de ECC). As amostras foram então avaliadas sensorialmente com relação a aceitação (global, textura e aparência) e intenção de compra, além de serem caracterizadas através de análises químicas, físico-químicas e físicas. Os resultados indicaram que o XY e ० ECC apresentam elevadas concentrações de compostos bioativos. Além disso, quando adicionados ao iogurte, a suplementação induziu mudanças nas propriedades químicas, físico-químicas e físicas do iogurte. Com relação aos testes sensoriais, todas as formulações apresentam uma boa aceitação sensorial. Esses resultados indicam que o iogurte pode ser considerado um veículo interessante para XY e ECC, que são produtos que apresentam elevadas concentrações de compostos bioativos que podem exercer efeitos benéficos à saúde humana.

Palavras-chave: Prebiótico; Produtos lácteos; Smallanthus sonchifolius; Anacardium occidentale.

\section{Introduction}

Cashew apple (Anacardium occidentale L.) extract (CAE) is a product obtained from the residual fibre after juice processing and presents high levels of bioactive compounds such as carotenoids (Abreu et al., 2013). Carotenoids, in addition to conferring a natural yellow colour, also exhibit antioxidant properties, of particular significance to human health, improving the antioxidant: reactive oxygen species balance, and hence reducing "oxidative stress", a critical factor in the pathogenic processes of various chronic disorders (Fiedor \& Burda, 2014). On the other hand, yacon (Smallanthus sonchifolius) - which is a perennial plant of the family Asteraceae, native to the Andean regions of South America - is an abundant source of fructooligosaccharides (FOS) (Campos et al., 2012; Ojansivu et al., 2011; Valentová et al., 2006). These prebiotic compounds can provide several health benefits such as increased absorption of minerals; production of vitamins; increased activity of live active beneficial cultures; and the inhibition of harmful bacteria in the digestive tract (Rolim, 2015). Other health benefits of FOS include providing a sense of fullness and satiety, which is important in decreasing the calorie intake and helping in weight control (Silva et al., 2017; Adriano et al., 2019). Regarding the technological aspects, yacon could be processed into various products, such as pickles, beverages and syrup, which is obtained by concentrating microfiltered yacon juice to 20-30\% FOS (Silva et al., 2018a, 2018b). This syrup has physical and sensory characteristics similar to those of honey and sugarcane syrup (Silva et al., 2017), and could therefore be used as a sugar replacement.

Yoghurt is a product highly desired by consumers, due to its healthy and convenient characteristics. According to Allgeyer et al. (2010), the popularity of dairy products fortified with prebiotics and probiotics continues to increase, since consumers desire flavourful foods that fulfil their health needs. However, modifications in the textural and sensory properties occur differently, depending on the type of prebiotic added (Allgeyer et al., 2010; Aryana et al., 2006; Canbulat \& Ozcan, 2015; Dello Staffolo et al., 2004; Madora et al., 2016; Rani \& Srividya, 2016; Sah et al., 2016), and therefore the instrumental and sensory testing of these compounds is critical when introducing them into products.

Thus the objective of the present work was to investigate the effects of supplementing natural yoghurt with yacon syrup (YS) and cashew apple extract (CAE) on the chemical, physical, physicochemical and sensory properties of the final product. 


\section{Material and methods}

\subsection{Yacon Syrup (YS) as a source of prebiotic compounds}

Raw yacon (S. sonchifolius) roots were obtained from a local market in Fortaleza, Ceará State, Brazil. Briefly, after washing and sanitizing the roots, the peel was removed manually and the edible portion cut into pieces $\left(1 \mathrm{~cm}^{3}\right)$ and immersed in a citric acid solution $(2.4 \mathrm{~g} / \mathrm{L})$ for $8 \mathrm{~min}$. to inactivate polyphenoloxidase. The small pieces were then homogenized in an industrial blender to obtain yacon pulp, which was stored at $-18 \pm 1{ }^{\circ} \mathrm{C}$. Subsequently, the yacon pulp was treated with Celluclast ${ }^{\circledR} 1.5 \mathrm{~L}$ and Pectinex ${ }^{\circledR}$ Ultra SP-L $(500 \mathrm{mg} / \mathrm{L}$ of each), filtered through a microfiltration system, and the clarified material concentrated to $71^{\circ}$ Brix under vacuum $(560 \mathrm{~mm} \mathrm{Hg})$ at a temperature of $60 \pm 5^{\circ} \mathrm{C}$. The syrup was stored at $5{ }^{\circ} \mathrm{C}$ until used.

\subsection{Cashew Apple Extract (CAE) as a source of carotenoids and phenolic compounds}

The cashew apple variety CCP-76 was obtained from Embrapa Agroindústria Tropical, located in Pacajus, Ceará State, Brazil. After removal of the cashew nuts, the cashew apple was washed and sanitized and the edible portion (cashew apple) pressed to obtain the whole non-pulpy juice and residual fibres which were treated as reported by Abreu et al. (2013). In this procedure, the fibres were first mixed with water $(1: 1 \mathrm{w} / \mathrm{w})$ and treated with Celluclast ${ }^{\circledR}(500 \mathrm{mg} / \mathrm{L})$ at $40{ }^{\circ} \mathrm{C}$ for 1 hour. The mixture was then pressed in a continuous helical type expeller (Incomap 300, Fortaleza, Brazil) with a nominal capacity of $300 \mathrm{~kg} / \mathrm{h}$ for juice production. This operation was repeated six times consecutively, reincorporating the extracts with the fibres each time. A yellow-coloured suspension was thus obtained, due to the presence of the carotenoids. This suspension was submitted to a microfiltration system as proposed by Abreu et al. (2013), always using the concentration mode up to a volumetric reduction ratio (VRR) of 14. The carotenoid fraction was thus concentrated in the retentate phase and called the cashew apple extract (CAE). An Armfield FT74x unit with a tubular heat exchanger was used to pasteurize the CAE. The CAE was fed into the tank, pumped through the heat exchanger to achieve the pre-determined pasteurization treatment $\left(85^{\circ} \mathrm{C}\right.$ for $\left.30 \mathrm{~s}\right)$, hot-filled into glass bottles, closed with caps and cooled in an ice/water bath. The pasteurized CAE was stored at $5{ }^{\circ} \mathrm{C}$ until used.

\subsection{Methods}

The YS and CAE were characterized using the following analyses:

- Colour: The colour was analysed using a Minolta Colorimeter (Model CR-400, Konica Minolta Sensing, Inc., Osaka, Japan), with the results based on three colour coordinates: $L^{*}$ (whiteness or brightness/darkness), $a^{*}$ (redness/greenness) and $b^{*}$ (yellowness/blueness). Based on the values for $\mathrm{L}^{*}$, $\mathrm{a}^{*}$ and $\mathrm{b}^{*}$, the chroma value $\left(\mathrm{c}^{*}\right)$, which is the colour saturation, was calculated, and from the relationship between $a^{*}$ and $b^{*}$, the colour hue angle $\left(h^{*}\right)$, which indicates the colour tone, was obtained. The $\Delta \mathrm{E}^{*}$ (colour difference) was defined according to Mokrzycki \& Tatol (2011);

- Water activity, total and reducing sugars and soluble solids: The water activity $\left(a_{w}\right)$ was measured at $25{ }^{\circ} \mathrm{C}$ using Aqualab equipment (Decagon Devices, Inc., model CX-2 T, Pullman, WA, USA). The total and reducing sugars were determined by the anthrone (Yemm \& Willis, 1954) and 3,5-dinitrosalicylic acid (DNS) (Miller, 1959) methods, respectively. The soluble solids content ( ${ }^{\circ}$ Brix) was determined using a digital refractometer (Pocket refractometer PAL-3, ATAGO, Japan) at $20.0 \pm 0.5^{\circ} \mathrm{C}$, as recommended by Association of Official Analytical Chemists (2005);

- pH and titratable acidity: The $\mathrm{pH}$ of the samples was measured using a digital $\mathrm{pH}$ meter (Hanna Instruments, Romania), and the titratable acidity, expressed as grams of citric acid per $100 \mathrm{~g}$ of product, was determined according to the AOAC methods (Association of Official Analytical Chemists, 2005); 
- Chemical composition: The protein content was determined using the Kjeldahl method (920.87 AOAC); the total lipid content by the Soxhlet extraction method ( $925.38 \mathrm{AOAC})$; ash by incineration at $550{ }^{\circ} \mathrm{C}$ in a muffle furnace for $6 \mathrm{~h}$ (923.03 AOAC); moisture by the AOAC method 925.09; and carbohydrates by difference (Association of Official Analytical Chemists, 2005);

- Fructooligosaccharides: The fructooligosaccharides were determined as described by Association of Official Analytical Chemists (2005), and the results expressed as g FOS per $100 \mathrm{~g}$ of product;

- Ascorbic acid: The methodology proposed by Strohecker \& Henning (1967) was used to determine the vitamin C content. A $5.0 \mathrm{~g}$ sample was weighed and diluted to $100 \mathrm{~mL}$ with oxalic acid. An aliquot of $5.0 \mathrm{~mL}$ of the extract was removed, $50 \mathrm{~mL}$ of distilled water added and the vitamin $\mathrm{C}$ content determined using Tillman's solution. The results were expressed in $\mathrm{mg} / 100 \mathrm{~g}$ of product;

- Total antioxidant capacity and total extractable polyphenols contents: The total antioxidant activity was measured by the ABTS (organic radical-scavenging capacity -2,2'-Azino-bis(3 ethylbenzothiazoline6-sulfonic acid), FRAP (Ferric Reducing Antioxidant Power) and DPPH (2,2-diphenyl-1-picrylhydrazil) methods, using the procedure developed by Larrauri et al. (1997) for extraction. The samples were extracted sequentially with $4 \mathrm{~mL}$ of methanol/water $(50: 50, \mathrm{v} / \mathrm{v})$ at $25^{\circ} \mathrm{C}$ for $1 \mathrm{~h}$, centrifuged at $25,400 \mathrm{~g}$ for $15 \mathrm{~min}$, the supernatant recovered, $4 \mathrm{~mL}$ of acetone/water $(70: 30, \mathrm{v} / \mathrm{v})$ added to the residue at $25^{\circ} \mathrm{C}$, allowed to extract for $1 \mathrm{~h}$ and then centrifuged under the same conditions. The methanolic and acetonic extracts were combined in a $10 \mathrm{~mL}$ flask, adding water to complete the volume. The $\mathrm{ABTS}^{+}$assay was based on the method developed by Miller et al. (1993) and the procedure described by Benzie \& Strain (1996) was used for the FRAP assay. For the DPPH method, the procedure described by Brand-Wiliams et al. (1995) was used. All these methods were used with the modifications suggested by Rufino et al. (2010). The results obtained in the ABTS and FRAP assays were expressed as $\mu \mathrm{M}$ Trolox and $\mu \mathrm{M} \mathrm{Fe} 2 \mathrm{SO}_{4} / \mathrm{g}$ of product, respectively. The total extractable polyphenols contents (TEP) contents were determined by the Folin-Ciocalteau method (Obanda et al., 1977) and the results expressed as mg GAE (gallic acid equivalent)/g of product;

- Total carotenoids: The methodology proposed by Higby (1962) was used to determine the carotenoid content of the cashew apple extract. The results were expressed in $\mathrm{mg} / 100 \mathrm{~g}$ of product.

\subsection{Microbiological analyses}

The total coliform and Escherichia coli counts were determined in the yacon syrup (YS) and cashew apple extract (CAE) according to Feng et al. (2002). The mould and yeast counts were determined according to Tournas et al. (2001) and the microbial safety parameter (Salmonella spp.) according to Andrews et al. (2014). The analyses were carried out according to the methodology described in the FDA Bacteriological Analytical Manual (Andrews et al., 2014; Feng et al., 2002)

\subsection{Preparation of the supplemented yoghurts}

Commercial natural yoghurt was acquired from local supermarkets in Fortaleza-CE, Brazil. The control (Formulation A) consisted of a non-supplemented yoghurt. For the other preparations, $40 \mathrm{~g}$ of YS was added to a $200 \mathrm{~g}$ portion of yoghurt, totalling approximately $11.16 \mathrm{~g}$ of FOS/portion. This value was below the tolerable dose indicated by Grabitske \& Slavin (2009), which was $16 \mathrm{~g} / \mathrm{day}$. This yoghurt, containing only YS (20\%), was named Formulation B, and the yoghurts supplemented with YS and CAE were named Formulation C ( $20 \%$ of YS plus $10 \%$ of CAE) or Formulation D ( $20 \%$ of YS plus $20 \%$ of CAE) (see Table 1). 
Table 1. Formulations of the yoghurt supplemented with yacon syrup (YS) and cashew apple extract (CAE).

\begin{tabular}{ccccc}
\hline & Formulation A & Formulation B & Formulation C & Formulation D \\
\hline Yacon syrup (\%) & 0 & 20 & 20 & 20 \\
Cashew apple extract (\%) & 0 & 0 & 10 & 20 \\
\hline
\end{tabular}

\subsection{Sensory tests}

The sensory tests of the yoghurt samples were carried out using 50 untrained panellists. The evaluation carried out was a consumer acceptance test with a 9-point hedonic scale for parameters such as texture, appearance and overall acceptance, where 9 corresponded to "like extremely" and 1 to "dislike extremely". The panellists were also asked to express their purchase intent on a 5-point scale, varying from "certainly would not buy" to "certainly would buy". The presentation of the yoghurt samples followed a balanced order, each treatment being served in $50 \mathrm{~mL}$ transparent plastic cups coded with a three-digit random code. The experimental protocol was submitted to and approved by the Ethical Research Committee of the State University of Ceara (UECE) ( $\mathrm{n}^{\circ}$ 05879912.0.0000.5534).

\subsection{Yogurt characterization}

The following analyses were carried out to characterize the yoghurts: $\mathrm{pH}$, soluble solids, titratable acidity, soluble solids/titratable acidity ratio, total and reducing sugars, water activity, and colour. The methodology of each analysis was described in 2.3 item.

The texture profile of the yoghurt samples was determined using a texture analyser (TA_XTEi) coupled with the Exponent Lite Express software. The yoghurt sample was compressed in a $50 \mathrm{~mL}$ plastic cup using a probe ( $20 \mathrm{~mm}$ long cylindrical probe) with a test speed of $2 \mathrm{~mm} / \mathrm{s}$, target distance of $2 \mathrm{~mm}$ and $5 \mathrm{~g}$ of trigger load. The hardness, adhesiveness, cohesiveness, gumminess and springiness of each yoghurt formulation were determined in triplicate batches.

\subsection{Statistical analysis}

The data were analysed by the analysis of variance using the statistical software Statistical Analysis System (SAS Institute, 2014). Significant differences between the means were determined using Fisher's protected Least Significant Difference test. The significant differences were determined at $\alpha=0.05$.

\section{Results and discussion}

\subsection{Characterization of the Yacon Syrup (YS) and Cashew Apple Extract (CAE)}

The results obtained in the characterization of the yacon syrup (YS) are summarized in Table 2. The YS showed water activity of 0.78 , soluble solids of $67.9^{\circ} \mathrm{Brix}$, moisture of $35.5 \%$ and a $\mathrm{pH}$ value of $4.0 \mathrm{pH}$. Considering the coordinates of the values L*, a* and $\mathrm{b}^{*}$, YS had a yellowish-reddish colour and also showed higher levels of carbohydrates and lower levels of proteins and lipids. These results were expected, since the raw material is recognized for its higher concentration of carbohydrates (such as fructooligosaccharides, FOS) and lower contents of lipids and proteins (Ojansivu et al., 2011). These oligosaccharides are known to be non-toxic, non-digestible and sweet, and are responsible for the prebiotic properties of yacon, ranging from $40 \%$ to $70 \%$ of the dry matter depending on several factors, such as variety, climatic conditions and storage conditions (Valentová et al., 2006; Lachman et al., 2007; Ojansivu et al., 2011).

The syrup, which is a concentrated product obtained from yacon, presented high levels of these bioactive compounds (27.9 g FOS/100 g of YS). Considering the Brazilian legislation for products with functional 
properties (Brasil, 2016), the amount of FOS must be higher than $2.5 \mathrm{~g}$ per portion of the product and the permitted claim is "As prebiotics, FOS contribute to a balanced equilibrium of the intestinal flora and their consumption should be associated with a balanced diet and a healthy lifestyle". Moreover, the YS also presented high levels of phenolic compounds (195.3 mg GAE/100 g of YS), which contribute to its antioxidant capacity (Campos et al., 2012).

The characterization of the cashew apple extract (CAE) is summarized in Table 2. It presented a high moisture content $(91.46 \%)$ and high water activity $(0.97)$. However, although these conditions are favourable for microbial growth, the extract showed low values for soluble solids ( $3.33^{\circ}$ Brix) and can be considered an acidic product $(\mathrm{pH}=3.6)$. Moreover, the CAE presented $0.18 \%$ carbohydrates, $1.95 \%$ proteins and $6.08 \%$ lipids. The high values for lipids were expected, since the $\mathrm{CAE}$ referred to the retentate of the microfiltration, composed of carotenoids and, consequently, lipids. Low levels of ascorbic acid were found in the CAE $(25.59 \mathrm{mg} / 100 \mathrm{~g})$, since this vitamin is water soluble and is present in the permeate. In the colorimetric analyses, the results indicated that the CAE presented a yellow colour $\left(b^{*}\right.$ values $\left.=49.65\right)$ due to its composition of carotenoids, as previously reported by Abreu et al. (2013).

Table 2. Chemical, physicochemical and physical characterization of yacon syrup (YS) and cashew apple extract (CAE) (results expressed as the mean \pm the standard deviation).

\begin{tabular}{|c|c|c|}
\hline Variables & Yacon syrup & Cashew apple extract \\
\hline Moisture (g/100 g) & $35.50 \pm 0.54$ & $91.46 \pm 0.03$ \\
\hline Total solids $(\mathrm{g} / 100 \mathrm{~g})$ & $64.49 \pm 0.54$ & $8.53 \pm 0.03$ \\
\hline Ash (g/100 g) & $2.72 \pm 0.13$ & $0.144 \pm 0.007$ \\
\hline $\mathrm{pH}$ & $4.06 \pm 0.08$ & $3.61 \pm 0.01$ \\
\hline Titratable acidity (g/100 g, as citric acid) & $2.45 \pm 0.02$ & $0.16 \pm 0.01$ \\
\hline Soluble solids $\left({ }^{\circ} \mathrm{Brix}\right)$ & $67.88 \pm 0.044$ & $3.33 \pm 0.18$ \\
\hline Water activity & $0.78 \pm 0.005$ & $0.974 \pm 0.007$ \\
\hline Ascorbic acid $(\mathrm{mg} / 100 \mathrm{~g})$ & $29.73 \pm 0.10$ & $25.59 \pm 0.09$ \\
\hline Proteins $(\mathrm{g} / 100 \mathrm{~g})$ & $1.65 \pm 0.032$ & $1.95 \pm 0.25$ \\
\hline Lipids $(\mathrm{g} / 100 \mathrm{~g})$ & $0.17 \pm 0.18$ & $6.08 \pm 0.92$ \\
\hline Carbohydrates $(\mathrm{g} / 100 \mathrm{~g})$ & $5980 \pm 0.55$ & $0.18 \pm 0.03$ \\
\hline Fructooligosaccharides $(\mathrm{g} / 100 \mathrm{~g})$ & $27.9 \pm 0.67$ & - \\
\hline Reducing sugars $(\mathrm{g} / 100 \mathrm{~g})$ & $21.61 \pm 0.22$ & $2.14 \pm 0.19$ \\
\hline Total sugars $(\mathrm{g} / 100 \mathrm{~g})$ & $45.00 \pm 0.04$ & $4.42 \pm 0.44$ \\
\hline $\mathrm{L}^{*}$ & $82.39 \pm 0.27$ & $55.61 \pm 0.70$ \\
\hline$a^{*}$ & $1.05 \pm 0.08$ & $3.96 \pm 0.64$ \\
\hline$b^{*}$ & $22.27 \pm 0.42$ & $49.65 \pm 0.63$ \\
\hline TEP (mg GAE/100 g) & $195.27 \pm 0.63$ & $78.46 \pm 0.94$ \\
\hline ABTS $(\mu \mathrm{M}$ Trolox/g) & $12.00 \pm 0.64$ & $9.34 \pm 0.38$ \\
\hline DPPH (g/g DPPH) & $998.76 \pm 1.49$ & $1420.19 \pm 0.65$ \\
\hline FRAP ( $\mu$ M ferrous sulphate/g) & $211.17 \pm 0.69$ & $482.92 \pm 0.92$ \\
\hline Total carotenoids (mg/100 g) & - & $14.04 \pm 0.11$ \\
\hline
\end{tabular}

TEP = Total Extractable Polyphenols; ABTS = organic radical-scavenging capacity - 2,2'-Azino-bis(3 ethylbenzothiazoline-6-sulfonic acid; $\mathrm{DPPH}=2,2$-diphenyl-1-picrylhydrazil); FRAP = Ferric Reducing Antioxidant Power.

The carotenoids are one of the largest and most important classes of plant pigments. In addition, synthetic or natural carotenoids and carotenoid-rich extracts are widely used as natural colorants in manufactured food products such as cakes, confectionery, ice creams and drinks. Their application in foods has been widely reported, such as in the studies reported by Aryana et al. (2006), who evaluated the addition of lutein to flavoured yoghurts and the modification of their physicochemical parameters; by Flores-Miranda et al. 
(2015), who evaluated yoghurts with the addition of nanodispersed $\beta$-carotene samples; and, more recently, Madora et al. (2016), who evaluated the physicochemical, microbiological and sensory properties of low-fat yoghurt fortified with carrot powder, rich in carotenoid compounds.

Carotenoids are known to be very efficient physical and chemical quenchers of singlet oxygen $\left({ }^{1} \mathrm{O}_{2}\right)$, as well as potent scavengers of other reactive oxygen species (ROS). This is of special significance, since the uncontrolled generation and concomitant increase of ROS levels in the body results in "oxidative stress", an essential contributor to the pathogenic processes of many diseases (Fiedor \& Burda, 2014). Their antioxidant properties have been well established and extensively reported in the literature (Jomova \& Valko, 2013; Fiedor \& Burda, 2014). As discussed above, the intense yellow colour of CAE is due to the carotenoid composition. In addition, the extract contains phenolic compounds (78.46 mg GAE/100 g of CAE), which are recognized as antioxidant compounds. The antioxidant activity could be observed by all the antioxidant methods tested (see Table 2).

\subsection{Yoghurt supplemented with YS and CAE: sensory tests and characterization}

The results obtained in the microbiological analyses indicated that the products were safe, and in accordance with the sanitary standards for food set by the Brazilian Ministry of Agriculture, Livestock and Food Supply and National Health Surveillance Agency. The products showed a mesophilic aerobic count to the order of 3-4 $\operatorname{logs}(\mathrm{CFU} / \mathrm{mL})$, while Salmonella spp., faecal coliforms, E. coli, yeasts and moulds were absent. For this reason, Thus the sensory evaluation could be applied. Table 3 presents the results obtained in the sensory evaluations of all the yoghurt formulations, as follows: Formulation A (natural yogurt, as control); Formulation B (yogurt supplemented with YS); Formulation C (yogurt supplemented with YS and $10 \%$ of CAE) and Formulation D (yogurt supplemented with YS and $20 \%$ of CAE). Formulation B showed the highest values for sensory acceptability (7.7), with mean scores in the "liked moderately" and "liked very much" categories, and was statistically different from the other samples. Moreover, there were no statistically significant differences between Formulations A, C and D $(p>0.05)$, indicating that the incorporation of YS in addition to CAE did not influence the acceptance of the product. However, this incorporation lowered the scores obtained for appearance, probably due to the intense yellow colour of the product, which could be considered as different from the consumer expectation for a natural yoghurt. Nevertheless, the purchase intention and texture acceptance were not statistically significant $(p>0.05)$ when these samples were compared with the control.

Table 3. Sensory characterization of yoghurt supplemented with yacon syrup (YS) and cashew apple extract (CAE).

\begin{tabular}{ccccc}
\hline & Formulation A & Formulation B & Formulation C & Formulation D \\
\hline Overall acceptance & $6.48^{\mathrm{b}} \pm 0.74$ & $7.67^{\mathrm{a}} \pm 1.12$ & $6.82^{\mathrm{b}} \pm 0.87$ & $6.61^{\mathrm{b}} \pm 0.83$ \\
Appearance & $7.57^{\mathrm{a}} \pm 1.23$ & $7.63^{\mathrm{a}} \pm 1.24$ & $6.42^{\mathrm{b}} \pm 0.67$ & $6.2^{\mathrm{b}} \pm 0.77$ \\
Texture & $6.86^{\mathrm{ab}} \pm 1.0$ & $7.46^{\mathrm{a}} \pm 1.23$ & $6.96^{\mathrm{b}} \pm 0.91$ & $7.00^{\mathrm{b}} \pm 0.91$ \\
\hline Purchase intention & $3.14^{\mathrm{b}} \pm 0.26$ & $4.22^{\mathrm{a}} \pm 0.97$ & $3.56^{\mathrm{b}} \pm 0.49$ & $3.33^{\mathrm{b}} \pm 0.45$ \\
\hline
\end{tabular}

Means followed by the same letter in the same line did not differ significantly $(p>0.05)$. Formulation $\mathrm{A}=$ control (non-supplemented yoghurt). Formulation $\mathrm{B}=$ yoghurt supplemented with $\mathrm{YS}$ ). Formulation $\mathrm{C}=$ yoghurt supplemented with $\mathrm{YS}$ and $10 \%$ of $\mathrm{CAE}$. Formulation $\mathrm{D}=$ yoghurt supplemented with YS and $20 \%$ of CAE.

Rani \& Srividya (2016) evaluated the effects of adding inulin, FOS and L. acidophilus to the formulation of a symbiotic yoghurt and concluded that the yoghurt formulations presented similar acceptability scores for "appearance" (7.5). However, the formulation containing FOS obtained the highest score for taste (8.0), and the overall acceptance was greater for the prebiotic yoghurt formulations (7.8) as compared to the control (7.1).

The texture is a property of foods always related to a chemical/ physical system consisting of a colloidal system formed by two non-miscible phases (Oroian et al., 2011). For dairy products, such as yoghurt, texture 
is an important sensory attribute (Rani \& Srividya, 2016) and supplementation with YS and CAE affected the textural properties of the yoghurts (Table 4). The samples analysed showed a wide spectrum for the textural properties, with hardness from 13.62 to 15.34 ; adhesiveness from -0.0023 to -8.67 ; springiness from 0.98 to 1.94; cohesiveness fom 0.83 to 0.89 and gumminess from 12.55 to 13.24. Except for hardness, no variable was determined for Formulation D, which represented the sample with the largest amounts of YS and CAE. Recently, Sah et al. (2016) showed differences in the textural properties of probiotic yoghurt fortified with fibre-rich pineapple peel powder. Seydin et al. (2005) showed that yoghurts containing inulin had a good flavour and smooth texture. Dello Staffolo et al. (2004) reported that the sensory attributes of yoghurt containing inulin were not significantly different from the sensory attributes of the control yoghurt and of yoghurts containing wheat or bamboo fibres.

Table 4. Textural characterization of yogurt supplemented with yacon syrup (YS) and cashew apple extract (CAE) (results expressed as mean and standard deviation).

\begin{tabular}{ccccc}
\hline & Formulation A & Formulation B & Formulation C & Formulation D \\
\hline Hardness $(\mathrm{g})$ & $15.34^{\mathrm{a}} \pm 0.44$ & $14.17^{\mathrm{b}} \pm 0.38$ & $13.62^{\mathrm{b}} \pm 0.16$ & $13.90^{\mathrm{b}} \pm 0.45$ \\
Adhesiveness & $-8.67^{\mathrm{b}} \pm 2.72$ & $-0.51^{\mathrm{a}} \pm 0.86$ & $-0.023^{\mathrm{a}} \pm 0.08$ & ND \\
Springiness & $0.98^{\mathrm{b}} \pm 0.008$ & $1.59^{\mathrm{a}} \pm 0.41$ & $1.94^{\mathrm{a}} \pm 0.06$ & ND \\
Cohesiveness & $0.83^{\mathrm{a}} \pm 0.001$ & $0.89^{\mathrm{a}} \pm 0.03$ & $0.88^{\mathrm{a}} \pm 0.12$ & ND \\
\hline Gumminess & $13.09^{\mathrm{a}} \pm 0.50$ & $13.24^{\mathrm{a}} \pm 0.53$ & $12.55^{\mathrm{a}} \pm 1.87$ & ND \\
\hline
\end{tabular}

Means followed by the same letter in the same line do not differ significantly $(p>0.05)$. Formulation $\mathrm{A}=$ control (non-supplemented yoghurt). Formulation $\mathrm{B}=$ yoghurt supplemented with YS. Formulation $\mathrm{C}=$ yoghurt supplemented with $\mathrm{YS}$ and $10 \%$ of $\mathrm{CAE}$. Formulation $\mathrm{D}=$ yoghurt supplemented with YS and $20 \%$ of CAE. N.D. $=$ not detected.

The results obtained in the chemical, physicochemical and physical characterizations of the yoghurts are summarized in Table 5. The addition of YS and CAE influenced all the characteristics of the yoghurts, including the $\mathrm{pH}$, soluble solids, titratable acidity, total and reducing sugars, water activity and colour ( $\mathrm{L}^{*}, \mathrm{a}^{*}$ and $\mathrm{b}^{*}$ parameters). The $\mathrm{pH}$ of the samples ranged from 4.06 to 3.75 , with the control sample showing higher values than the samples with added YS and CAE. This result might be due to the low $\mathrm{pH}$ value of CAE $(\mathrm{pH}=3.61)$, as previously reported (see Table 2$)$.

Table 5. Chemical, physicochemical and physical characterizations of yoghurts supplemented with yacon syrup (YS) and cashew apple extract (CAE) (results expressed as the mean and standard deviation).

\begin{tabular}{ccccc}
\hline & Formulation A & Formulation B & Formulation C & Formulation D \\
pH value & $4.06^{\mathrm{a}} \pm 005^{*}$ & $3.81^{\mathrm{b}} \pm 0.01$ & $3.75^{\mathrm{b}} \pm 0.01$ & $3.75^{\mathrm{b}} \pm 0.02$ \\
Soluble solids ( ${ }^{\circ}$ Brix) & $8.37^{\mathrm{c}} \pm 0.21$ & $18.87^{\mathrm{a}} \pm 0.06$ & $18.60^{\mathrm{ab}} \pm 0.1$ & $18.30^{\mathrm{b}} \pm 0.26$ \\
Titratable acidity (\% as citric acid) & $0.64^{\mathrm{b}} \pm 0.03$ & $1.06^{\mathrm{a}} \pm 0.05$ & $1.03^{\mathrm{a}} \pm 0.04$ & $1.00^{\mathrm{a}} \pm 0.08$ \\
\hline SS/TA & $12.98^{\mathrm{b}} \pm 0.46$ & $17.79^{\mathrm{a}} \pm 0.96$ & $18.02^{\mathrm{a}} \pm 0.72$ & $18.32^{\mathrm{a}} \pm 1.47$ \\
\hline Total sugars (\%) & $2.89^{\mathrm{b}} \pm 0.14$ & $10.57^{\mathrm{a}} \pm 0.29$ & $10.41^{\mathrm{a}} \pm 0.46$ & $10.48^{\mathrm{a}} \pm 0.21$ \\
Reducing sugars (\%) & $1.94^{\mathrm{c}} \pm 0.09$ & $4.00^{\mathrm{a}} \pm 0.30$ & $3.68^{\mathrm{b}} \pm 0.05$ & $3.61^{\mathrm{b}} \pm 0.08$ \\
\hline Water activity & $0.992^{\mathrm{a}} \pm 0.01$ & $0.986^{\mathrm{a}} \pm 0.01$ & $0.979^{\mathrm{ab}} \pm 0.01$ & $0.969^{\mathrm{b}} \pm 0.01$ \\
$\mathrm{~L}^{*}$ & $99.17^{\mathrm{a}} \pm 0.06$ & $91.29^{\mathrm{b}} \pm 0.07$ & $88.95^{\mathrm{c}} \pm 0.08$ & $85.83^{\mathrm{d}} \pm 0.10$ \\
$\mathrm{a}^{*}$ & $-4.60^{\mathrm{b}} \pm 0.05$ & $-2.76^{\mathrm{a}} \pm 0.1$ & $-4.82^{\mathrm{c}} \pm 0.01$ & $-5.77^{\mathrm{d}} \pm 0.02$ \\
$\mathrm{~b}^{*}$ & $12.87^{\mathrm{d}} \pm 0.03$ & $13.55^{\mathrm{c}} \pm 0.04$ & $28.09^{\mathrm{b}} \pm 0.02$ & $32.18^{\mathrm{a}} \pm 0.02$ \\
\hline$\Delta \mathrm{E}^{*}$ & - & $7.92^{\mathrm{c}} \pm 0.04$ & $10.25^{\mathrm{b}} \pm 0.01$ & $13.37^{\mathrm{a}} \pm 0.03$ \\
\hline
\end{tabular}

Means followed by the same letter in the same line do not differ significantly $(p>0.05)$. Formulation $\mathrm{A}=$ control (non-supplemented yoghurt). Formulation $\mathrm{B}=$ yoghurt supplemented with YS). Formulation $\mathrm{C}=$ yoghurt supplemented with $\mathrm{YS}$ and $10 \%$ of $\mathrm{CAE}$. Formulation $\mathrm{D}=$ yoghurt supplemented with YS and $20 \%$ of CAE. SS/TA = Soluble solids/titratable acidity ratio.

Colour is an important attribute of foods. It is the first characteristic perceived by consumers and thus often influences consumer preference (Sah et al., 2016). Table 5 shows the values obtained for the brightness ( $\left.L^{*}\right)$, redness $\left(\mathrm{a}^{*}\right)$, yellowness $\left(\mathrm{b}^{*}\right)$ and $\Delta \mathrm{E}$ of the prebiotic yoghurts supplemented with YS and/or CAE. The colour parameters of the yoghurts differed with the addition of CAE, due to its yellow intense colour. The $\mathrm{L}^{*}$ values of the non-supplemented control yoghurts were significantly higher than those of the YS- and/or CAE-supplemented 
yoghurts $(p<0.05)$. The a* values increased with the incorporation of CAE, shifting towards yellow due to the supplementation. Moreover, yoghurt fortification with YS and/or CAE produced a significant effect on the $\Delta \mathrm{E}^{*}$, which indicated a greater total colour difference when the samples were compared with the control $(\Delta \mathrm{E}>3)$.

\section{Conclusion}

The yacon syrup and cashew apple extract showed high concentrations of bioactive compounds, such as fructooligosaccharides and carotenoids, which exhibited prebiotic and antioxidant properties. When these products were used for yoghurt supplementation, alterations in the chemical, physicochemical and physical characteristics were observed. Regarding the sensory evaluation, the yoghurt supplemented only with yacon syrup was awarded the highest scores for all the parameters evaluated (overall acceptance, appearance and texture) and also obtained the best values for purchase intention when compared with the other formulations. Moreover, it was observed that supplementation with $10 \%$ or $20 \%$ of cashew apple extract decreased the visual acceptance of the yoghurts compared to the control. However, all the other sensory parameters (overall acceptance and texture) and the purchase intention were not influenced by the addition of cashew apple extract. In general, yoghurt may be considered an interesting vehicle for YS and CAE, which are products with high levels of bioactive compounds that may exert beneficial effects on human health.

\section{References}

Abreu, F. P., Dornier, M., Dionisio, A. P., Carail, M., Caris-Veyrat, C., \& Dhuique-Mayer, C. (2013). Cashew apple (Anacardium occidentale L.) extract from by-product of juice processing: A focus on carotenoids. Food Chemistry, 138(1), 25-31. PMid:23265451. http://dx.doi.org/10.1016/j.foodchem.2012.10.028

Adriano, L. S., Dionísio, A. P., Abreu, F. A. P., Carioca, A. A. F., Zocolo, G. J., Wurlitzer, N. J., Pinto, C. O., Oliveira, A. C., \& Sampaio, H. A. C. (2019). Yacon syrup reduces postprandial glycemic response to breakfast: A randomized, crossover, doubleblind clinical trial. Food Research International, 108682. http://dx.doi.org/10.1016/j.foodres.2019.108682

Allgeyer, L. C., Miller, M. J., \& Lee, S. Y. (2010). Sensory and microbiological quality of yogurt drinks with prebiotics and probiotics. Journal of Dairy Science, 93(10), 4471-4479. PMid:20854980. http://dx.doi.org/10.3168/jds.2009-2582

Andrews, W. H., Jacobson, A., \& Hammack, T. S. (2014). Salmonella. In U.S. Food and Drug Administration - FDA (Ed.), Bacteriological analytical manual online (8th ed., Chap. 5). Rockville: FDA. Retrieved in 2018, March 15, from https://www.fda.gov/food/foodscienceresearch/laboratorymethods/ucm114664.htm

Aryana, K. J., Barnes, H. T., Emmick, T. K., Mcgrew, P., \& Moser, B. (2006). Lutein is stable in strawberry yogurt and does not affect its characteristics. Journal of Food Science, 71(6), S467-S472. http://dx.doi.org/10.1111/j.1750-3841.2006.00080.x

Association of Official Analytical Chemists - AOAC. (2005). Official Methods of Analysis of the Association of AOAC International (18th ed.). Arlington: AOAC International.

Benzie, I. F. F., \& Strain, J. J. (1996). The ferric reducing ability of plasma (FRAP) as a measure of antioxidant power: The FRAP assay. Analytical Biochemistry, 239(1), 70-76. PMid:8660627. http://dx.doi.org/10.1006/abio.1996.0292

Brand-Wiliams, W., Cuvelier, M. E., \& Berset, C. (1995). Use of a free radical method to evaluate antioxidant activity. Food Science and Technology, 28(1), 25-30.

Brasil. Ministério da Saúde. Agência Nacional de Vigilância Sanitária - ANVISA. (2016). Alimentos com alegações de propriedades funcionais e ou de saúde. Brasília. Retrieved in 2018, July 2, from http://portal.anvisa.gov.br/alimentos/alegacoes Campos, D., Betalleluz-Pallardel, I., Chirinos, R., Aguilar-Galvez, A., Noratto, G., \& Pedreschi, R. (2012). Prebiotic effects of yacon (Smallanthus sonchifolius Poepp. \& Endl), a source of fructooligosaccharides and phenolic compounds with antioxidant activity. Food Chemistry, 135(3), 1592-1599. PMid:22953898. http://dx.doi.org/10.1016/j.foodchem.2012.05.088

Canbulat, Z., \& Ozcan, T. (2015). Effects of short-chain and long-chain inulin on the quality of probiotic yogurt containing Lactobacillus rhamnosus. Journal of Food Processing and Preservation, 39(6), 1251-1260. http://dx.doi.org/10.1111/jfpp.12343 Dello Staffolo, M., Martino, M., \& Bevilacqua, A. (2004). Influence of dietary fiber addition on sensory and rheological properties of yogurt. International Dairy Journal, 14(3), 263-268. http://dx.doi.org/10.1016/j.idairyj.2003.08.004

Feng, P., Weagant, S. D., \& Grant, M. A. (2002). Enumeration of Escherichia coli and the coliform bacteria. In U.S. Food and Drug Administration - FDA (Ed.), Bacteriological analytical manual online (Vol. 5, pp. 1-14). Rockville: FDA. Retrieved in 2017, October 16, from http://www.cfsan.fda.gov/ ebam/bam-4.html

Fiedor, J., \& Burda, K. (2014). Potential role of carotenoids as antioxidants in human health and disease. Nutrients, 6(2), 466488. PMid:24473231. http://dx.doi.org/10.3390/nu6020466 
Flores-Miranda, G. A., Valencia-Del-Toro, G., \& Yáñez-Fernandez, J. (2015). Evaluation of color stability of yogurt pigmentation with $\beta$-carotene nanodispersions. Advances in Bioresearch, 6, 128-135.

Grabitske, H. A., \& Slavin, J. L. (2009). Gastrointestinal effects of low-digestible carbohydrates. Critical Reviews in Food Science and Nutrition, 49(4), 327-360. PMid:19234944. http://dx.doi.org/10.1080/10408390802067126

Higby, W. K. (1962). A simplified method for determination of some the carotenoid distribution in natural and carotene-fortified orange juice. Journal of Food Science, 27(1), 42-49. http://dx.doi.org/10.1111/j.1365-2621.1962.tb00055.x

Jomova, K., \& Valko, M. (2013). Health protective effects of carotenoids and their interactions with other biological antioxidants. European Journal of Medicinal Chemistry, 70, 102-110. PMid:24141200. http://dx.doi.org/10.1016/j.ejmech.2013.09.054

Lachman, J., Fernández, E. C., Viehmannová, I., Šulc, M., \& Ėepková, P. (2007). Total phenolic content of yacon (Smallanthus sonchifolius) rhizomes, leaves, and roots affected by genotype. New Zealand Journal of Crop and Horticultural Science, 35(1), 117-123. http://dx.doi.org/10.1080/01140670709510175

Larrauri, J. A., Rupérez, P., \& Saura-Calixto, F. (1997). Effect of drying temperature on the stability of polyphenols and antioxidant activity of red grape pomace peels. Journal of Agricultural and Food Chemistry, 45(4), 1390-1393. http://dx.doi.org/10.1021/jf960282f

Madora, E. P., Thakhani, T. K., \& Mashau, E. M. (2016). Physicochemical, microbiological and sensory properties of low fat yoghurt fortified with carrot powder. International Journal of Agricultural and Biological Engineering, 9, 118-124.

Miller, G. L. (1959). Use of dinitrosalicylic acid reagent for determination of reducing sugars. Analytical Chemistry, 31(3), 426428. http://dx.doi.org/10.1021/ac60147a030

Miller, N. J., Rice-Evans, C., Davies, M. J., Gopinathan, V., \& Milner, A. (1993). A novel method for measuring antioxidant capacity and its application to monitoring the antioxidant status in premature neonates. Clinical Science, 84(4), 407-412. PMid:8482045. http://dx.doi.org/10.1042/cs0840407

Mokrzycki, W., \& Tatol, M. (2011). Color difference Delta E: A survey. Machine Graphics and Vision, Warszawa, 20, 383-411.

Obanda, M., Owuor, P. O., \& Taylor, S. J. (1977). Flavanol composition and caffeine content of green leaf as quality potential indication of kenyan black teas. Journal of the Science of Food and Agriculture, 74(2), 209-215.

http://dx.doi.org/10.1002/(SICl)1097-0010(199706)74:2<209::AID-JSFA789>3.0.CO;2-4

Ojansivu, I., Ferreira, C. L., \& Salminen, S. (2011). Yacon, a new source of prebiotic oligosaccharides with a history of safe use. Food Science \& Technology International, 22(1), 40-46. http://dx.doi.org/10.1016/j.tifs.2010.11.005

Oroian, M. A., Escriche, I., \& Gutt, G. (2011). Rheological, textural, color and physicochemical properties of some yogurt products from the spanish market. Food and Environment Safety Journal, 10, 24-29.

Rani, K. S., \& Srividya, N. (2016). Effect of inulin, fructooligosaccharides and L. acidophilus in formulating a symbiotic yoghurt. Asian Journal of Dairy and Food Research, 35(1), 37-40. http://dx.doi.org/10.18805/ajdfr.v35i1.9250

Rolim, P. M. (2015). Development of prebiotic food products and health benefits. Food Science and Technology, 35(1), 35. http://dx.doi.org/10.1590/1678-457X.6546

Rufino, M. S. M., Alves, R. E., Brito, E. S., Pérez-Jiménez, J., Saura-Calixto, F., \& Mancini-Filho, J. (2010). Bioactive compounds and antioxidant capacities of 18 non-traditional tropical fruits from Brazil. Food Chemistry, 2(4), 996-1002. http://dx.doi.org/10.1016/j.foodchem.2010.01.037

Sah, B. N. P., Vasiljevic, T., Mckechnie, S., \& Donkor, O. N. (2016). Physicochemical, textural and rheological properties of probiotic yogurt fortified with fibre-rich pineapple peel powder during refrigerated storage. Lebensmittel-Wissenschaft + Technologie, 65, 978-986. http://dx.doi.org/10.1016/j.Iwt.2015.09.027

SAS Institute. (2014). SAS user's guide: Statistics version 11.0. Cary: SAS Institute.

Seydin, Z. B. G., Sarikus, G., \& Okur, O. D. (2005). Effect of inulin and dairy-Lo as fat replacers on the quality of set type yogurt. Milchwissenschaft. Milk Science International, 60, 51-55.

Silva, M. F. G., Dionisio, A. P., Abreu, F. A. P., Brito, E. S., Wurlitzer, N. J., Silva, L. M. A., Ribeiro, P. R. V., Rodrigues, S., Taniguchi, C. A. K., \& Pontes, D. F. (2018a). Evaluation of nutritional and chemical composition of yacon syrup using ${ }^{1}$ H NMR and UPLC-ESI-Q-TOF-MS E. Food Chemistry, 245, 1239-1247. PMid:29287348.

http://dx.doi.org/10.1016/j.foodchem.2017.11.092

Silva, M. F. G., Dionísio, A. P., Abreu, F. A. P., Pinto, C. O., Silva, L. M. A., Brito, E. S., Wurlitzer, N. J., Lima, A. C. V., Rodrigues, S., Gomes, W. F., \& Pontes, D. F. (2018b). Optimization of enzymatic treatment to produce yacon juice clarified by microfiltration with high levels of chlorogenic acid and fructooligosaccharides. Journal of Food Processing and Preservation, 42(6), e13641. http://dx.doi.org/10.1111/jfpp.13641

Silva, M. F. G., Dionísio, A. P., Carioca, A. A. F., Adriano, L. S., Pinto, C. O., Abreu, F. A. P., Wurlitzer, N. J., Araújo, I. M., Garruti, D. S., \& Pontes, D. F. (2017). Yacon syrup: Food applications and impact on satiety in healthy volunteers. Food Research International, 100(Pt 1), 460-467. PMid:28873709. http://dx.doi.org/10.1016/j.foodres.2017.07.035

Strohecker, R., \& Henning, H. M. (1967). Análises de vitaminas: Métodos comprovados. Madrid: Paz Montalvo.

Tournas, V., Stack, M. E., Mislivec, P. B., Koch, H. A., \& Bandler, R. (2001). Yeasts, molds and mycotoxins. In U.S. Food and Drug Administration - FDA (Ed.), Bacteriological analytical manual online (8th ed., Chap. 18). Rockville: FDA. Retrieved in 2018, March 15, from http://www.fda.gov/Food/FoodScienceResearch/LaboratoryMethods/ucm071435.htm

Valentová, K., Lebeda, A., Dolezalová, I., Jirovský, D., Simonovska, B., Vovk, I., Kosina, P., Gasmanová, N., Dziechciarková, M., \& Ulrichová, J. (2006). The biological and chemical variability of yacon. Journal of Agricultural and Food Chemistry, 54(4), 1347-1352. PMid:16478259. http://dx.doi.org/10.1021/jf052645u 
Sensory acceptance and characterization of yoghurt supplemented with yacon syrup and cashew apple extract as a source of bioactive compounds

Mendes, A. H. L. et al.

Yemm, E. W., \& Willis, A. J. (1954). The estimation of carbohydrate in plant extracts by anthrone. The Biochemical Journal, 57(3), 508-514. PMid:13181867. http://dx.doi.org/10.1042/bj0570508

Funding: The authors are grateful to the Brazilian Agricultural Research Corporation (EMBRAPA), Coordination for the Improvement of Higher Education Personnel (CAPES) and National Council for Scientific and Technological Development (CNPq) for their financial support.

Received: July 13, 2018; Accepted: June 06, 2019 